\title{
The Combined Effect of Volume Water Supply and Varieties on Physiological Aspects, Growth, and Yield of Red Beetroot (Beta vulgaris L.) in Dryland Jatikerto, Indonesia
}

\author{
Nur Edy Suminarti ${ }^{1}$, Tika Noviana Dewi ${ }^{2}$, Aninda Nur Fajrin ${ }^{3}$
}

Department of Agricultural, Faculty of Agriculture, Brawijaya University, Indonesia

\begin{abstract}
Increasing public awareness of living a healthy life, causing red beetroot demand in Indonesia has increased. However, with increasingly limited area of the plateau to the development of the plant, causing its development are directed to dry land are still many obstacles, such as limited availability of water for the plant level, and the high air temperature. Therefore, research that aims to obtain information about the right water needs and tolerant varieties on dry land needs to be done. A greenhouse experiment was conducted in UB's experimental station in Jatikertot village from June to September 2019. This study used a randomized complete block design (RCBD), consisting of 10 treatment combinations, namely the volume of water supply (350,550,750, 950, and 1150) $\mathrm{mm}$ water/season + varieties (ie Vikima and Ayumi), repeated 3 times. F test at 5\% is used to determine the effect of treatments, while differences between treatments were referred to Honestly Significant Difference (HSD) value at 5\%. The highest yield which includes chlorophyll $a-b$ content, stomata density, root length, leaf surface area, total dry weight of plants and fresh weight of tubers/ plants was obtained in water supply volume of $1150 \mathrm{~mm} / \mathrm{season}+$ Ayumi varieties. While the lowest was obtained in the volume of $350-550 \mathrm{~mm}$ water/season for both varieties for all variables observed.
\end{abstract}

Keywords - Water requirements, Dry land, Red beet root varieties, Stomata density, Chlorophyll content.

\section{INTRODUCTION}

Red beetroot (Beta vulgaris L.) is increasingly popular in Indonesia because its tubers can not only be used as raw materials for the cosmetics industry or natural dyes but more importantly, it can be used to maintain the health of the human body [18]. The extent of such utilization associated with full enough minerals such as potassium, magnesium, phosphorus, copper, and iron contained in the bulbs. Vitamins A, C, D, E, K, as well as protein, fat, carbohydrates, sugar, fiber, calories, and even betasianine and folic acid were also found in these tubers [25 ]. Due to the fairly complete content of nutrients and vitamins, red beetroot can be used to prevent cancer, reduce blood pressure and maintain heart health, help facilitate digestion, and weight loss [18 ]. Based on the importance of such utilization, the demand for red beetroot in Indonesia has increased by around 2 to $5 \%$. However, the request can not be fulfilled because of the limited level of availability of these tubers.
Red beetroot are generally planted in the highlands which are marked by low temperatures, around $22.7{ }^{\circ} \mathrm{C}$ $25.1{ }^{\circ} \mathrm{C}$. On the other hand, the growth of horticultural commodities in Indonesia has increased significantly. As a result, competition in land use cannot be avoided. This is the reason for the limited circulation of bits in many traditional markets or supermarkets in Indonesia. Therefore, in an effort to increase the production of red beets, the development will be directed to dry land whose land is still quite large. However, with the many obstacles that must be faced in farming on dry land, causing this land cannot be fully utilized for agricultural activities [11 ]. One obstacle that must be faced in red beetroot cultivation in dry land is the high daily average air temperature which reaches $24^{\circ} \mathrm{C}$ to $31^{\circ} \mathrm{C}$ [21]. At high temperatures, as long as it is within the tolerance, they have a positive effect on plant growth and development. However, when the temperature has exceeded the tolerance limits, its impact on plant physiological disorders due to damage to the enzyme. High temperatures will also spur faster transpiration rates, and if not followed by adequate levels 
of water availability in the soil, plants will experience water stress. Moreover, one of the main constraints on dry land is the low level of availability of water for crops. In water stress conditions, the leaves of the plant appear to wither due to the inhibition of protein and chlorophyll biosynthesis. Water shortages also resulted in inhibition of initiation and differentiation on the apical meristem and cell enlargement, which leads to the inhibition of the development of roots, stem extension, and expansion of leaves [12]. The next impact is more rapid aging plant or senescense that causes the rate of photosynthesis decreases. Considering the important role of the water, research that aims to obtain precise information about the water requirements of red beetroot plants in dry land needs to be done.

Besides water, the selection of the right variety is also the key to the success of red beetroot cultivation in a dry land. This is because there is no precise information about the level of water requirements that are appropriate for red beetroot plants that are planted on dry land. Therefore, through this research, it is expected to be able to give the right answer about the level of water requirements that are appropriate for red beetroot varieties grown in a dry land. This information becomes important which is not only focused on the yield of tubers but also useful as a guideline in the management and maintenance of red beetroot plants in dry land. Basically every plant has a different character, and one of them can be expressed through the ability of varieties to adapt. For tolerant varieties, they will still be able to grow and develop normally even with new environmental changes. However, for sensitive varieties will show symptoms of withering as a result of the inhibition of protein and chlorophyll biosynthesis [19].

\section{MATERIALS AND METHODS}

\subsection{Description of the study area}

The greenhouse experiment has been carried out in the Universitas Brawiyaja Experimental Garden, located in Jatikerto Village, Malang Regency, Indonesia from June to September 2019. The location is located at an altitude of
$330 \mathrm{~m}$ above sea level. Climatologically the average annual rainfall is around $1200 \mathrm{~mm}$ with an average daily temperature between $24^{\circ} \mathrm{C}-31^{\circ} \mathrm{C}$. The soil type is classified as Inceptisol with dusty loam texture with the proportion of sand (28\%): dust $(60 \%)$ : clay (12\%).

\subsection{Research material}

As planting material is Vikima and Ayumi's red beetroot seeds of varieties which has been aged 18 days after sowing. Polybags with a diameter of $20 \mathrm{~cm}$ as a place of planting, and dusty loam soil tekstur as planting medium. $\mathrm{N}$ fertilizer in the form of urea $(46 \% \mathrm{~N})$, phosphorus $\left(\mathrm{SP}_{36}: 36 \% \mathrm{P}_{2} \mathrm{O}_{5}\right)$, and potassium $(\mathrm{KCl}: 60 \%$ $\mathrm{K}_{2} \mathrm{O}$ ) respectively of $250 \mathrm{~kg}$ urea ha-1, $50 \mathrm{~kg} \mathrm{SP}_{36} \mathrm{ha}^{-1}$, and $50 \mathrm{~kg} \mathrm{KCl} \mathrm{ha}^{-1}$ were applied in this study.

\subsection{Determination of field capacity}

Measurement of field capacity in this experiment is necessary, due to the uniformity of the water content in each of the planting medium (polybags) on all treatments before giving water treatment applied. The method used is free drainage, which according to [10] the stages are as follows: First, the soil that will be used as a planting medium is crushed, then air-dried and then sieved with a sieve with a diameter of $3 \mathrm{~mm}$. The sieved soil is then put into a polybag, as much as $8 \mathrm{~kg} /$ polybag, then filled with water until it drips. Soil that has been saturated is then stored for $2 \times 24$ hours until no longer dripping, and then weighed, expressed in weight of wet soil (WWS). The WWS is then oven at a temperature of $108^{\circ} \mathrm{C}$ for $1 \times 24$ hours to get the soil dry weight (DWS). Field capacity (FC) is determined using the formula:

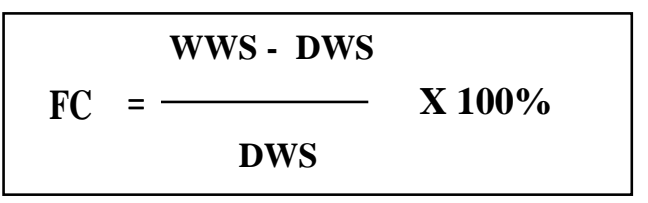

\subsection{Determination of water supply/day/polybag}

Determination of water provision is based on (1) the value of crop coefficient (CC), (2) the value of HLO, and (3) the volume of water supplied/season (Table 1) [7] 
International Journal of Environment, Agriculture and Biotechnology, 5(2)

Mar-Apr, 2020 / Available: https://ijeab.com/

Table 1. Water supply volume/day based on crop coefficient value, HLO value, and water supply volume/season

\begin{tabular}{|l|c|c|c|c|}
\hline \multicolumn{3}{|c|}{ CC of red beetroot plant } & HLO value & $\begin{array}{l}\text { Volume of water supplied (mm) / } \\
\text { season }\end{array}$ \\
\hline Phase of plant growth & $\begin{array}{c}\text { Long phase of plant } \\
\text { growth (days) }\end{array}$ & $\begin{array}{c}\text { CC } \\
\text { value }\end{array}$ & & \\
\hline Initial growth & 15 & 0.72 & $2.2 \times 10^{6} \mathrm{~kg}$ of soil / ha & $350 \mathrm{~mm} / \mathrm{season}$ \\
\hline active vegetative & 15 & 0.81 & $2.2 \times 10^{6} \mathrm{~kg}$ of soil / ha & $550 \mathrm{~mm} / \mathrm{season}$ \\
\hline tuber formation & 35 & 1.04 & $2.2 \times 10^{6} \mathrm{~kg}$ of soil / ha & $750 \mathrm{~mm} / \mathrm{season}$ \\
\hline $\begin{array}{l}\text { Tuber enlargement- } \\
\text { harvest }\end{array}$ & 15 & 0.70 & $2.2 \times 10^{6} \mathrm{~kg}$ of soil / ha & $950 \mathrm{~mm} / \mathrm{season}$ \\
\hline Total & & 3.27 & $2.2 \times 10^{6} \mathrm{~kg}$ of soil / ha & $1150 \mathrm{~mm} / \mathrm{season}$ \\
\hline
\end{tabular}

Based on Table 1, it can be calculated the volume of water supplied /day/polybags with the following stages : (1) Convert the needs of water/season to hectares (eg 350 $\mathrm{mm} / \mathrm{season}=350 \mathrm{1} / \mathrm{m}^{2}=3.5 \times 10^{6} \mathrm{l} / \mathrm{ha}$ ), (2) Determination of water/ polybag requirements is based on the calculation of water requirements/ha divided by the value of HLO, multiplied by the weight of the soil/polybag: [ $\left(3.5 \times 10^{6} 1 /\right.$ ha) $\left./\left(2.2 \times 10^{6} \mathrm{~kg} / \mathrm{ha}\right)\right] \times[8 \mathrm{~kg}]=12.731 /$ polybag. $(3)$ Determination of water requirements/day/polybag for the initial growth phase is as follows: the results of point 2, multiplied by the result of dividing the value of $\mathrm{CC}(0.72)$ by the amount of $\mathrm{CC}$

(3.27), then divided by the length of the growth phase (15 days): [(12.73 $1 /$ polybag) $\times[(0.72 / 3.27)] / 15$ days $=$ $0.186861 / \mathrm{kg} / \mathrm{polybag} /$ day $=186.86 \mathrm{ml} / \mathrm{polybag} /$ day . Through the same calculation, then in Table 2 presented the volume of water given per plant/ day/ polybag which is based on the phase of plant growth, the value of $\mathrm{CC}$ and a long phase of growth.

Table 2. The volume of water supplied/day/polybags based on the volume of water supplied/season, plant growth stage, the value of CC and long phases of plant growth

\begin{tabular}{|c|c|c|c|c|c|c|}
\hline \multirow[b]{2}{*}{ Phase of plant growth } & \multirow{2}{*}{$\begin{array}{c}\text { Long } \\
\text { phase of } \\
\text { plant } \\
\text { growth } \\
\text { (days) }\end{array}$} & \multicolumn{5}{|c|}{$\begin{array}{l}\text { The volume of water supplied }(\mathrm{ml}) / \text { day/polybags based on the volume of } \\
\text { water supplied / season }(\mathrm{mm})\end{array}$} \\
\hline & & $\begin{array}{c}350 \\
\mathrm{~mm} / \mathrm{season}\end{array}$ & $\begin{array}{c}550 \\
\mathrm{~mm} / \mathrm{season}\end{array}$ & $\begin{array}{c}750 \\
\mathrm{~mm} / \mathrm{season}\end{array}$ & $\begin{array}{l}950 \\
\mathrm{~mm} / \mathrm{season}\end{array}$ & $\begin{array}{c}1150 \\
\mathrm{~mm} / \mathrm{season}\end{array}$ \\
\hline Initial growth & 15 & $186.86 \mathrm{ml}$ & $293.33 \mathrm{ml}$ & $399.96 \mathrm{ml}$ & $506.73 \mathrm{ml}$ & $613.36 \mathrm{ml}$ \\
\hline Active vegetative & 15 & $212.22 \mathrm{ml}$ & $333.33 \mathrm{ml}$ & $454.50 \mathrm{ml}$ & $575.83 \mathrm{ml}$ & $697.0 \mathrm{ml}$ \\
\hline Tuber formation & 35 & $116.39 \mathrm{ml}$ & $182.86 \mathrm{ml}$ & $249.33 \mathrm{ml}$ & $315.89 \mathrm{ml}$ & $382.35 \mathrm{ml}$ \\
\hline $\begin{array}{l}\text { Tuber enlargement- } \\
\text { harvest }\end{array}$ & 15 & $178.22 \mathrm{ml}$ & $280.0 \mathrm{ml}$ & $381.78 \mathrm{ml}$ & $483.70 \mathrm{ml}$ & $585.48 \mathrm{ml}$ \\
\hline
\end{tabular}

\subsection{Experimental design}

Experiments using Randomized Complete Block Design (RCBD) and repeated 3 times. The combination of the volume of water supply and varieties as a treatment, consisting of 10 kinds, namely: (1) $350 \mathrm{~mm}$ water / season + varietas Vikima (P1), (2) $550 \mathrm{~mm}$ water/season + varietas Vikima (P2),(3) $750 \mathrm{~mm}$ water/season + varietas Vikima (P3), (4) $950 \mathrm{~mm}$ water/season + varietas Vikima
(P4), (5) $1150 \mathrm{~mm}$ water/season + varietas Vikima (P5), (6) $350 \mathrm{~mm}$ water/season + varietas Ayumi (P6), (7) 550 $\mathrm{mm}$ water/season + varietas Ayumi (P7), (8) $750 \mathrm{~mm}$ water/season + varietas Ayumi (P8), (9) $950950 \mathrm{~mm}$ water/season + varietas Ayumi (P9), (10) $1150 \mathrm{~mm}$ water/season + varietas Ayumi (P10). F test at 5\% is used to determine the effect of treatments, while differences between treatments were referred to Honestly Significant 
Difference (HSD) value at 5\%. Regression analysis is used to explore relationships between two or more variables observed [9]

\subsection{Research implementation}

Transplanting is done when the seedlings have formed two leaves that have been fully open (around the age of 18 days after sowing) by placing one seed/polybag which has been filled with soil $8 \mathrm{~kg}$ and in conditions of field capacity. Phosphorus fertilizer was applied at the start of planting all doses, namely 0.23 g $\mathrm{SP}_{36} /$ polybag, while nitrogen and potash fertilizers respectively of $1.14 \mathrm{~g}$ urea/polybag and $0.23 \mathrm{~g} \mathrm{KCl} /$ polybag be granted gradually. Phase $I$ is applied when the plant was 7 days after planting (dap) 1/3 of the dose, and the remaining $2 / 3$ was applied at 14 daps. Fertilizer is applied to each hole of fertilizer with a depth of $7 \mathrm{~cm}$ and a distance of $5 \mathrm{~cm}$ from the plant and then covered with compost. The application of the water supply is done after the plant was 14 days after planting with the assumption that plants has been able to adapt to their environment.

\subsection{Data collection}

Observation's physiological aspects that include the measurement of chlorophyll-a ,b and stomata density is done at the maximum vegetative phase (40 daps). As for agronomic observations which include measurements of root length, leaf surface area, total dry weight of plants, and fresh weight of tubers/plants carried out destructively at harvest (60 daps) by taking four samples per treatment.

\subsubsection{Chlorophyll content}

Measurement of chlorophyll content refers to methods spectrophotometer, which according [3] are as follows:

Chlorophyll -a: (12.21 x $\lambda 663)-(2.81 \times \lambda 646)$,

Chlorophyll -b: $(20.13 \times \lambda 646)-(5.03 \times \lambda 663)$.

\subsubsection{Stomata density}

Measurement of stomata density using a microscope with magnification 40 times to obtain a clear visualization of stomata images. The stages of implementation according [6] to are as follows:

1. Printing stomata at 11:00 AM with transparent nail polish on the leaf surface, and slowly lift it when it is dry

2. Stomata mold that has been lifted from the surface of the leaf, and then put in a plastic bag that had been labeled treatment

3. Stomata observed with a microscope with a magnification of 40 times, until a clear visualization of stomata
4. Counting the total number of stomata observed in a wide field of view (ie: $257 \mu \mathrm{m} \times 345 \mu \mathrm{m}$ ), or equal to $0.088 \mathrm{~mm}^{2}$

5. Determine the density of stomata using the formula [14]

$$
\text { Stomata density }=\quad \frac{\text { Number of stomata }}{\text { Unit area of field view }}
$$

\subsubsection{Root length}

Root length is measured from the root tip to the base of the stem, using a ruler

\subsubsection{Leaf surface area}

Leaf surface area was measured using a leaf area meter type LI-3100 C for leaves that had been fully opened, excluding young or senescence leaves. Leaf samples are placed above the glass lens in a non-folded or nonoverlapping position. Records were taken for all sample leaves from four sample plants per treatment, then averaged. The leaf surface area value is determined by multiplying the average value of the recording by the correction factor. Correction factors can be sought by dividing the measurement value of the actual paper area (for example $100 \mathrm{~cm}^{2}$ ) with the value of the paper area that has been measured by leaf area meters, for example 99 $\mathrm{cm}^{2}$. So the value of the correction factor is $99 \mathrm{~cm}^{2} / 100$ $\mathrm{cm}^{2}=0.99[24]$

\subsubsection{Total dry weight of plants}

Measurement of the total dry weight of plant by using oven-type OVL 12 with a temperature of $81^{\circ} \mathrm{C}$. Before drying, roots, stems, leaves, and tubers should be separated, because every part of the plant requires different drying time to achieve a constant dry weight. The plant parts that have been separated then put into a cement bag, and then put into the oven. Weighing is done after a constant dry weight is achieved, then added up [24].

\subsubsection{Fresh weight of tubers/plant}

Fresh weight of tubers/plant obtained by weighing the tubers after being separated from the roots and leaves by using an analytical balance Scout- pro type.

\section{RESULT AND DISCUSSION}

\subsection{Result}

Measurement of physiological aspects is carried out when the plant is 40 days after planting with the consideration that the plant has entered the maximum 
vegetative phase. While the agronomic observations were made at harvest time (60 daps)

\subsubsection{Physiological aspects}

\subsubsection{Chlorophyll content}

There was a significant effect at $\mathrm{p}=0.05$ of the combination treatment of water supply and varieties on the measurement of Chlorophyll a, b content at 40 dap (Table 3).

Table 3. The average chlorophyll a and b content in various treatment combinations of water supply and varieties at the age of 40 dap

\begin{tabular}{lccc}
\hline Treatment & Code & \multicolumn{2}{c}{ Average chlorophyll content $(\mu \mathrm{g} / 2 \mathrm{~g} \mathrm{fw})$} \\
\cline { 2 - 4 } & & Chlorophyll-a & Chlorophyll \\
\hline $350 \mathrm{~mm}$ of water/ season + Vikima varieties & $\mathrm{P} 1$ & $11.63 \mathrm{a}$ & $0.84 \mathrm{a}$ \\
$550 \mathrm{~mm}$ of water/ season + Vikima varieties & $\mathrm{P} 2$ & $16.18 \mathrm{abc}$ & $2.47 \mathrm{~b}$ \\
$750 \mathrm{~mm}$ of water/ season + Vikima varieties & $\mathrm{P} 3$ & $16.68 \mathrm{c}$ & $2.55 \mathrm{~b}$ \\
$950 \mathrm{~mm}$ of water/ season + Vikima varieties & $\mathrm{P} 4$ & $17.07 \mathrm{~cd}$ & $4.06 \mathrm{~cd}$ \\
$1150 \mathrm{~mm}$ of water/ season + Vikima varieties & $\mathrm{P} 5$ & $30.09 \mathrm{e}$ & $4.30 \mathrm{~d}$ \\
$350 \mathrm{~mm}$ of water/ season + Ayumi varieties & $\mathrm{P} 6$ & $11.96 \mathrm{a}$ & $1.14 \mathrm{a}$ \\
$550 \mathrm{~mm}$ of water/ season + Ayumi varieties & $\mathrm{P} 7$ & $15.68 \mathrm{abc}$ & $1.45 \mathrm{a}$ \\
$750 \mathrm{~mm}$ of water/ season + Ayumi varieties & $\mathrm{P} 8$ & $16.67 \mathrm{bc}$ & $2.45 \mathrm{~b}$ \\
$950 \mathrm{~mm}$ of water/ season + Ayumi varieties & $\mathrm{P} 9$ & $21.50 \mathrm{~d}$ & $3.44 \mathrm{c}$ \\
$1150 \mathrm{~mm}$ of water/ season + Ayumi varieties & $\mathrm{P} 10$ & $31.44 \mathrm{e}$ & $4.50 \mathrm{~d}$ \\
\hline BNJ 5\% & & 4.68 & 0.80
\end{tabular}

Note: Numbers are accompanied by the same letters in the same column are not significantly different by HSD 5\%. dap: days after planting, fw : fresh weight

Table 3 shows that the higher chlorophyll-a content was obtained in treatments P5 and P10 when compared to other treatments, respectively 30.09 and $31.44 \mu \mathrm{g} / 2 \mathrm{~g}$ fw, and both showed no significant differences at $\mathrm{p}=0.05$. While the lower one was obtained in the treatments P1, P2, P6 and P7, respectively 11.63, 16.18, 11.96, and 15.68 $\mu \mathrm{g} / 2 \mathrm{~g} \mathrm{fw}$, and the four treatments showed no significant difference at $\mathrm{p}=0.05$. However, for the P2 and P7 treatments, chlorophyll-a is generated also not significantly different with treatment $\mathrm{P} 3, \mathrm{P} 4$ and $\mathrm{P} 8$, respectively 16.68 , 17:07, and $16.67 \mu \mathrm{g} / 2 \mathrm{~g}$ fw. Although the three treatments are still able to produce chlorophyll-a higher compared to the treatment P1 and P6, but lower when compared to the treatment of P5,P9 and P10. The chlorophyll-a content also showed no significant difference at $\mathrm{p}=0.05$ in $\mathrm{P} 4$ and $\mathrm{P} 9$ treatments, respectively 17.07 and $21.50 \mu \mathrm{g} / 2 \mathrm{~g}$ fw. As for chlorophyll-b, the lower results obtained in the treatment of P1, P6, and P7, respectively $0.84,1: 14$, dan1.45, and the three treatments showed no significantly different at $\mathrm{p}=$ 0.05. In treatments P2 $(2.47 \mu \mathrm{g} / 2 \mathrm{~g}$ fw $), \mathrm{P} 3(2.55 \mu \mathrm{g} / 2 \mathrm{~g}$ fw $)$, and P8 $(2.45 \mu \mathrm{g} / 2 \mathrm{~g} \mathrm{fw})$, the chlorophyll-b content produced was also not significantly different at $\mathrm{p}=0.05$. However, these results are still higher than treatment P1, P6, and P7, but lower compared to the treatment P4, P5, P9 and P10 that has reached 4.06, 4.30, 3.44, and $4.50 \mu \mathrm{g} / 2 \mathrm{~g}$ fw. Higher chlorophyll-b content was obtained in treatments P5 and P10, although not significantly different from treatment $\mathrm{P} 4$.

\subsubsection{Stomata density}

There was a significant effect at $\mathrm{p}=0.05$ of the combination treatment of water supply and varieties on the measurement of stomata density at the age of 40 days after planting (Table 4). 
International Journal of Environment, Agriculture and Biotechnology, 5(2)

Mar-Apr, 2020 / Available: https://ijeab.com/

Table 4. Average stomata density in various treatment combinations of water supply and varieties at the age of 40 dap

\begin{tabular}{|c|c|c|c|}
\hline \multirow[b]{2}{*}{ Treatment } & \multicolumn{3}{|c|}{ Stomata density } \\
\hline & Code & $\begin{array}{c}\text { (field of view }(257 \mathrm{x} \\
\left.345 / \mathrm{cm}^{3}\right) / \mathrm{mm}^{2}\end{array}$ & Category \\
\hline $350 \mathrm{~mm}$ of water/ season + Vikima varieties & $\mathrm{P} 1$ & $111.74 \mathrm{a}$ & Low \\
\hline $550 \mathrm{~mm}$ of water/ season + Vikima varieties & $\mathrm{P} 2$ & $123.11 \mathrm{a}$ & Low \\
\hline $750 \mathrm{~mm}$ of water/ season + Vikima varieties & P3 & $172.35 \mathrm{bc}$ & Low \\
\hline $950 \mathrm{~mm}$ of water/ season + Vikima varieties & $\mathrm{P} 4$ & $192.23 \mathrm{c}$ & Low \\
\hline $1150 \mathrm{~mm}$ of water/ season + Vikima varieties & P5 & $264.20 \mathrm{~d}$ & Medium \\
\hline $350 \mathrm{~mm}$ of water/ season + Ayumi varieties & P6 & $117.42 \mathrm{a}$ & Low \\
\hline $550 \mathrm{~mm}$ of water/ season + Ayumi varieties & P7 & $135.42 \mathrm{abc}$ & Low \\
\hline $750 \mathrm{~mm}$ of water/ season + Ayumi varieties & P8 & $176.14 \mathrm{c}$ & Low \\
\hline $950 \mathrm{~mm}$ of water/ season + Ayumi varieties & P9 & $257.58 \mathrm{~d}$ & Medium \\
\hline $1150 \mathrm{~mm}$ of water/ season + Ayumi varieties & $\mathrm{P} 10$ & $284.09 \mathrm{~d}$ & Medium \\
\hline
\end{tabular}

BNJ 5\% 48.08

Note: Numbers are accompanied by the same letters in the same column are not significantly different by HSD 5\%. dap: days after planting.

Table 4 shows that the lower stomatal density generated by the treatment of $\mathrm{P} 1, \mathrm{P} 2, \mathrm{P} 6$, and $\mathrm{P} 7$, respectively amounted to $111.74,123.11,117.42$, and $135.42 / \mathrm{mm}^{2}$, and the fourth treatment showed no significantly different at $\mathrm{p}$ $=0.05$. However, for the treatment of $\mathrm{P} 7$, the resulting stomatal density is not significantly different from the treatment of $\mathrm{P} 3, \mathrm{P} 4$, and $\mathrm{P} 8$, respectively $172.35,192.23,176.14 / \mathrm{mm} 2$, but lower when compared to the treatment of P5, P9 and P10. In treatments P5, P9, and P10 the highest stomata density was obtained compared to the other treatments, each of 264.20, 257.58, and 284.09/ $\mathrm{mm}^{2}$, and all showed no significant difference at $\mathrm{p}=0.05$. Fig. 1 to 10 present the levels of stomata density from various combinations of volume water supply + varieties.
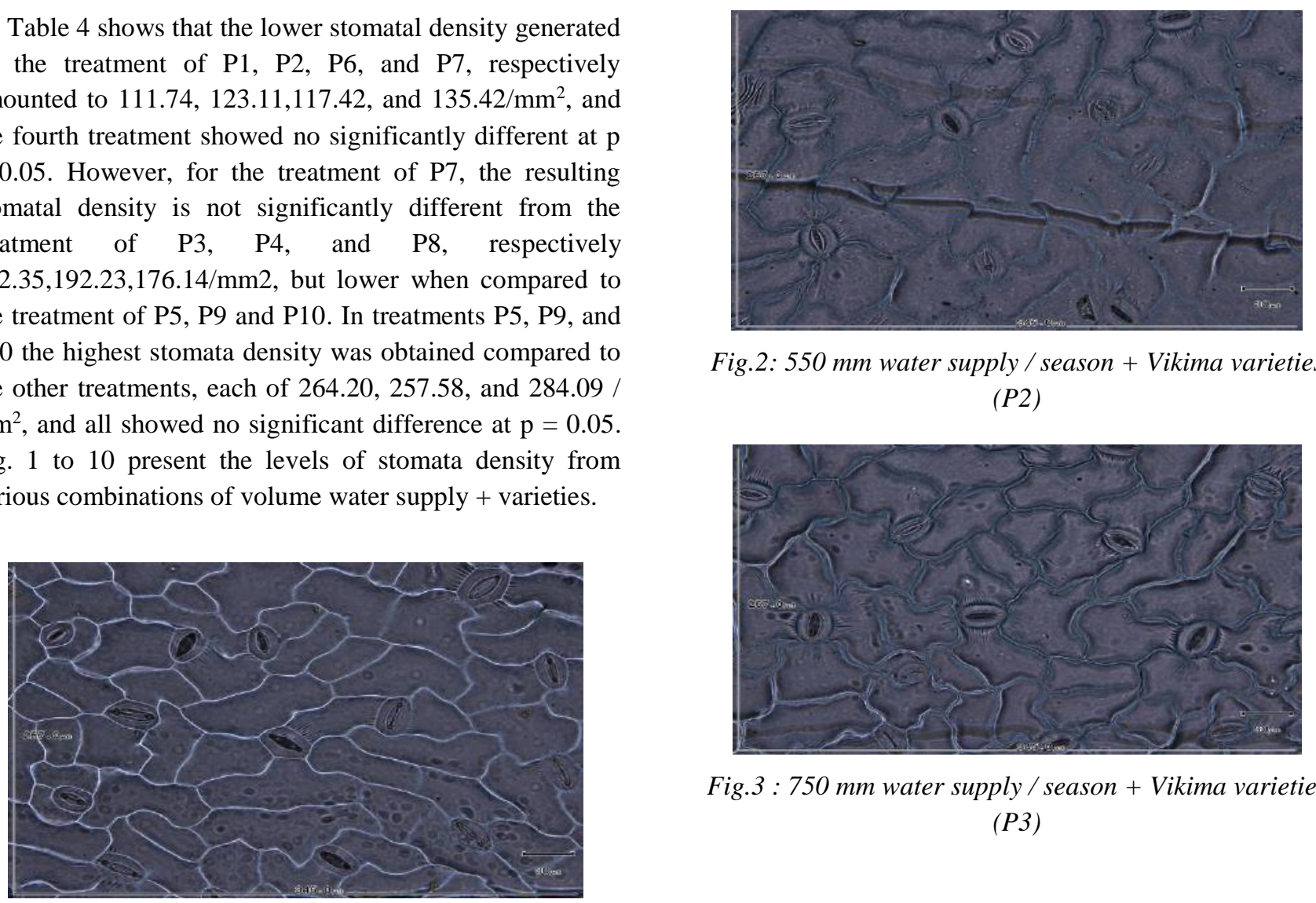

Fig.2: $550 \mathrm{~mm}$ water supply / season + Vikima varieties (P2)

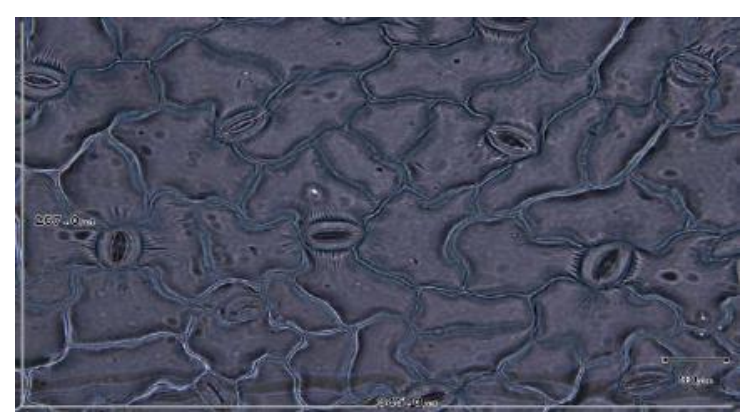

Fig.3 : 750 mm water supply / season + Vikima varieties (P3)

Fig.1: $350 \mathrm{~mm}$ water supply / season + Vikima varieties (P1) 


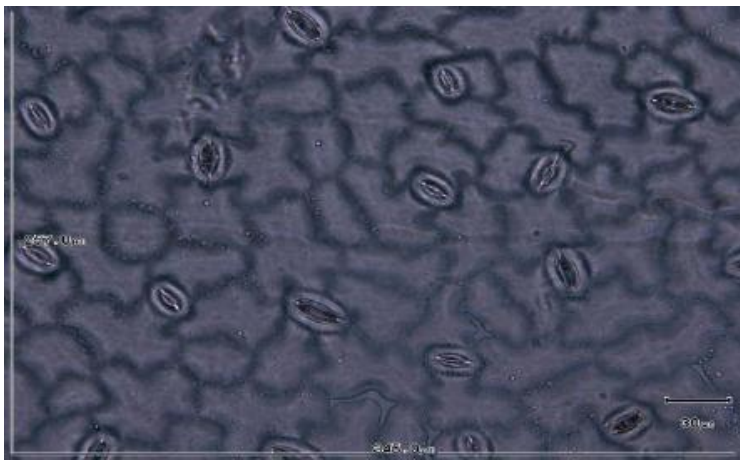

Fig.4 : 950 mm water supply/season + Vikima varieties (P4)

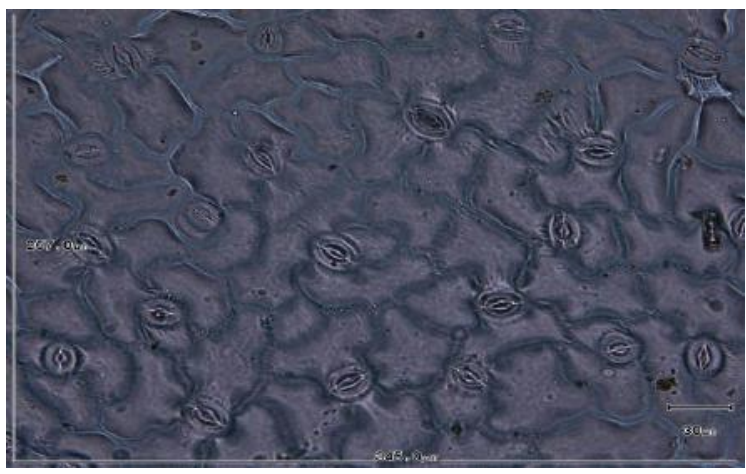

Fig.5 : $1150 \mathrm{~mm}$ water supply/season + Vikima varieties (P5)

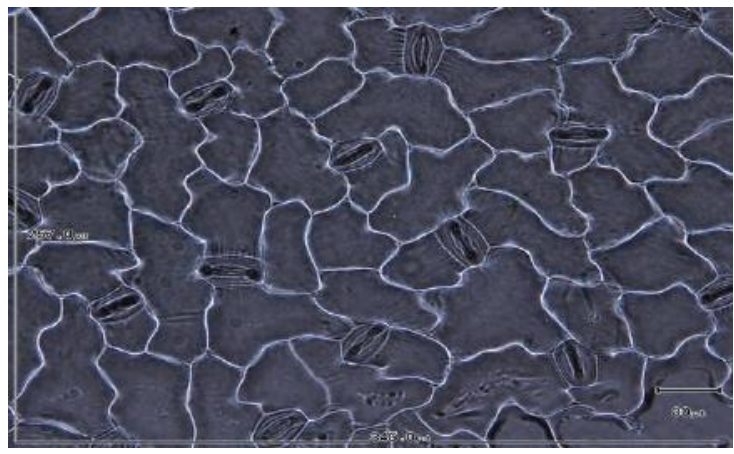

Fig.6 : 350 mm water supply / season + Ayumi varieties (P6)

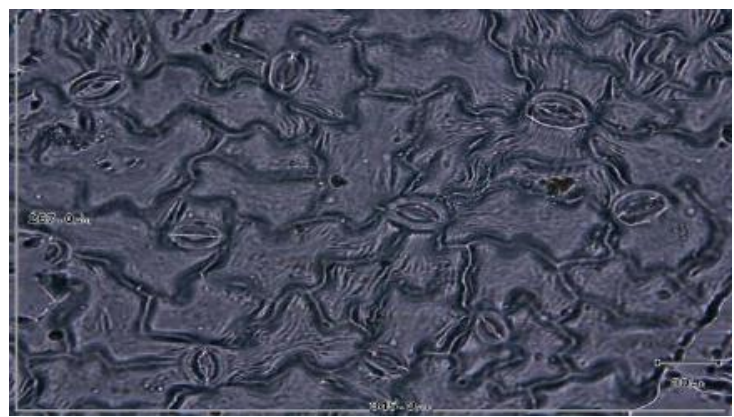

Fig. 7 : $550 \mathrm{~mm}$ water supply / season + Ayumi varieties (P7)

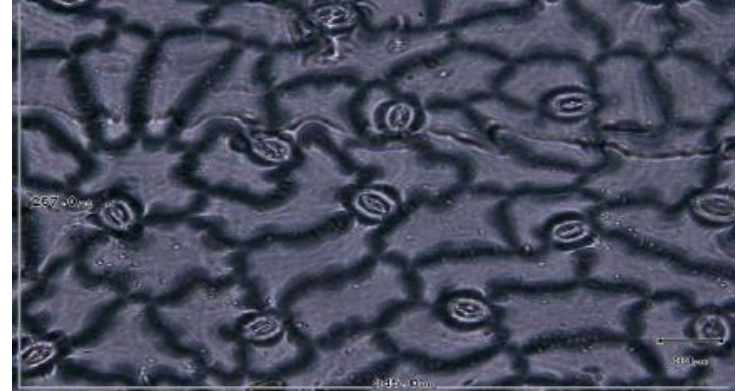

Fig.8 : $750 \mathrm{~mm}$ water supply / season + Ayumi varieties (P8)

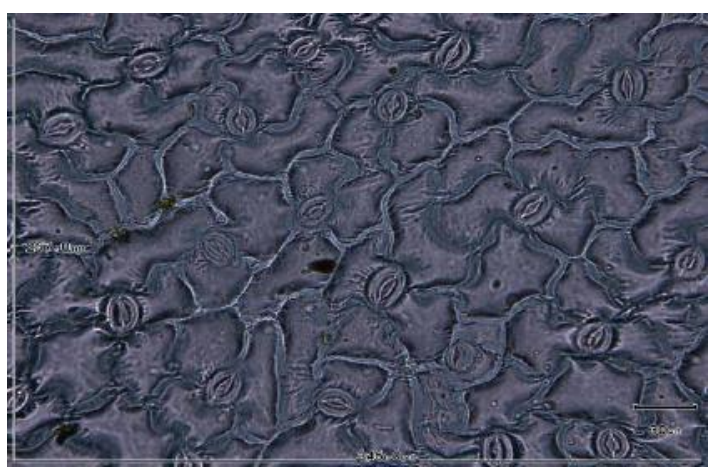

Fig.9 : $950 \mathrm{~mm}$ water supply / season + Ayumi varieties (P9)

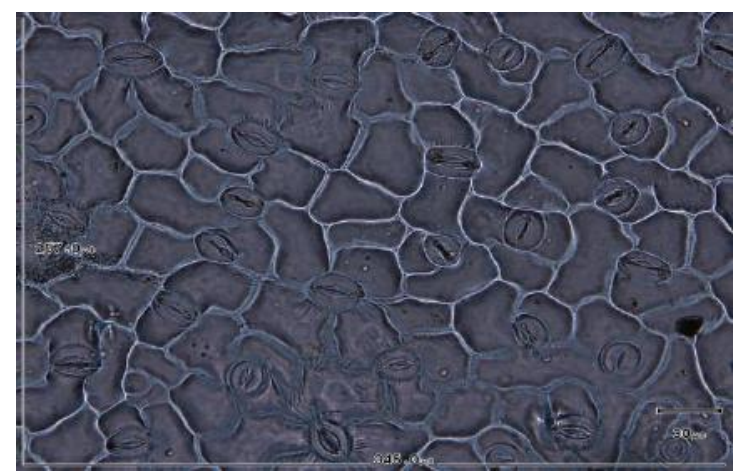

Fig.10 : $1150 \mathrm{~mm}$ water supply /season + Ayumi varieties (P10)

\subsubsection{Agronomic observations}

\subsubsection{Root length, Leaf surface area, Total dry weight of plants}

There was a significant effect at $\mathrm{p}=0.05$ of the combination treatment of water supply and varieties on the measurement of root length, leaf surface area, total dry weight of plants at harvest as presented in Table 5 . 
Table 5. The average root length, leaf surface area, total dry weight of plants in various combination treatment of water supply and varieties at harvest (60 daps)

\begin{tabular}{|c|c|c|c|c|}
\hline \multirow{2}{*}{ Treatment } & \multirow{2}{*}{ Code } & \multicolumn{3}{|c|}{$\begin{array}{l}\text { The average root length, leaf surface area, total dry } \\
\text { weight of plants at harvest }\end{array}$} \\
\hline & & $\begin{array}{l}\text { Root length } \\
\quad(\mathrm{cm})\end{array}$ & $\begin{array}{l}\text { Leaf surface } \\
\text { area }\left(\mathrm{cm}^{2}\right)\end{array}$ & $\begin{array}{l}\text { Total dry } \\
\text { weight }(\mathrm{g})\end{array}$ \\
\hline $350 \mathrm{~mm}$ of water/ season + Vikima varieties & $\mathrm{P} 1$ & $5.33 \mathrm{a}$ & $452.82 \mathrm{a}$ & $9.36 \mathrm{a}$ \\
\hline $550 \mathrm{~mm}$ of water/ season + Vikima varieties & $\mathrm{P} 2$ & $7.17 \mathrm{ab}$ & $564.83 \mathrm{ab}$ & $12.03 \mathrm{a}$ \\
\hline $750 \mathrm{~mm}$ of water/ season + Vikima varieties & P3 & $9.00 \mathrm{bcd}$ & $795.85 \mathrm{bcd}$ & $18.08 \mathrm{~b}$ \\
\hline $950 \mathrm{~mm}$ of water/ season + Vikima varieties & $\mathrm{P} 4$ & $9.67 \mathrm{~cd}$ & $858.80 \mathrm{~d}$ & $20.89 \mathrm{~b}$ \\
\hline $1150 \mathrm{~mm}$ of water/ season + Vikima varieties & P5 & $10.17 \mathrm{~d}$ & $1357.86 \mathrm{e}$ & $26.78 \mathrm{c}$ \\
\hline $350 \mathrm{~mm}$ of water/ season + Ayumi varieties & P6 & $6.67 \mathrm{a}$ & $520.24 \mathrm{a}$ & $10.89 \mathrm{a}$ \\
\hline $550 \mathrm{~mm}$ of water/ season + Ayumi varieties & P7 & $7.33 \mathrm{ab}$ & $559.43 \mathrm{ab}$ & $11.22 \mathrm{a}$ \\
\hline $750 \mathrm{~mm}$ of water/ season + Ayumi varieties & P8 & $9.00 \mathrm{bcd}$ & $843.43 \mathrm{~cd}$ & $19.60 \mathrm{~b}$ \\
\hline $950 \mathrm{~mm}$ of water/ season + Ayumi varieties & P9 & $10.0 \mathrm{~d}$ & $1262.35 \mathrm{e}$ & $21.32 \mathrm{~b}$ \\
\hline $1150 \mathrm{~mm}$ of water/ season + Ayumi varieties & $\mathrm{P} 10$ & $12.5 \mathrm{e}$ & $1797.05 \mathrm{f}$ & $35.54 \mathrm{~d}$ \\
\hline HSD 5\% & & 2.28 & 254.27 & 5.18 \\
\hline
\end{tabular}

Note: Numbers are accompanied by the same letters in the same column are not significantly different by HSD 5\%. dap: days after planting.

Table 5 shows that shorter roots were obtained at treatments $\mathrm{P} 1, \mathrm{P} 2, \mathrm{P} 6$, and $\mathrm{P} 7$, respectively 5.33, 7.17, 6.67 , and $7.33 \mathrm{~cm}$. Although for the treatment $\mathrm{P} 2$ and $\mathrm{P} 7$, root length produced is not significantly different at $\mathrm{p}=$ 0.05 with treatment $\mathrm{P} 3$ and $\mathrm{P} 8$, respectively along $9 \mathrm{~cm}$. While the root length produced by the treatment is also not significantly different from the treatment P4, P5, and P9, respectively along $9.67,10: 17$, and $10.0 \mathrm{~cm}$. Although the root length generated by the third treatment is still longer when compared with the treatment P1, P2, P6, and P7.The longest root was obtained at treatment P10, which is $12.5 \mathrm{~cm}$.

Table 5 also shows that a narrower leaf surface area was obtained in treatments P1, P2, P6, and P7, and the four treatments showed no significant difference at $\mathrm{p}=$ 0.05. The leaf surface area was 452.82, 564.83, 520.24 and $559.43 \mathrm{~cm}^{2}$, respectively. However, for P2 and P7 treatments, the leaf surface area produced was not significantly different from P3 treatment, which was $795.85 \mathrm{~cm}^{2}$. While for the P3 treatment, the leaf surface area produced was also not significantly different from the P4 and P8 treatments, respectively $858.80 \mathrm{~cm}^{2}$ and $843.43 \mathrm{~cm}^{2}$. While for the P3 treatment, the leaf surface area produced was also not significantly different from the P4 and P8 treatments, respectively $858.80 \mathrm{~cm}^{2}$ and $843.43 \mathrm{~cm}^{2}$, although these results were still higher than the treatments P1, P2, P6, and P7. Treatment of P5 and $\mathrm{P} 9$, leaf surface area produced was not significantly different at $\mathrm{p}=0.05$, but it was wider when compared to other treatments, except for treatment P10. The most extensive leaf surface was obtained in treatment P10, which is an area of $1797.05 \mathrm{~cm}^{2}$. In the measurement of the total dry weight of plants, the highest yield was obtained in treatment P10, which amounted to $35.54 \mathrm{~g} /$ plant, then followed by treatment P5, which amounted to $26.78 \mathrm{~g} /$ plant. While the lower one was obtained at treatments $\mathrm{P} 1, \mathrm{P} 2, \mathrm{P} 6$, and $\mathrm{P} 7$, respectively 9.36, 12.03, 10.89 , and $11.22 \mathrm{~g} /$ plant. The same thing was also found in the treatments of $\mathrm{P} 3, \mathrm{P} 4, \mathrm{P} 8$, and $\mathrm{P} 9$, respectively 18.08, 20.89, 19.60, and amounting to $21.32 \mathrm{~g} / \mathrm{plant}$. Table 5 can also be explained that the volume of water supplied various varieties Ayumi able to provide better results than Vikima varieties. Although statistically, significant differences do not occur in all treatments for water treatment, except for treatments P5 and P10. However, there is a tendency that the value of Ayumi generally higher than Vikima varieties at various observation variables such as root length, leaf surface area, as well as the total dry weight of the plant. Differences in response to both varieties as shown in Fig. 11 to 13 . 


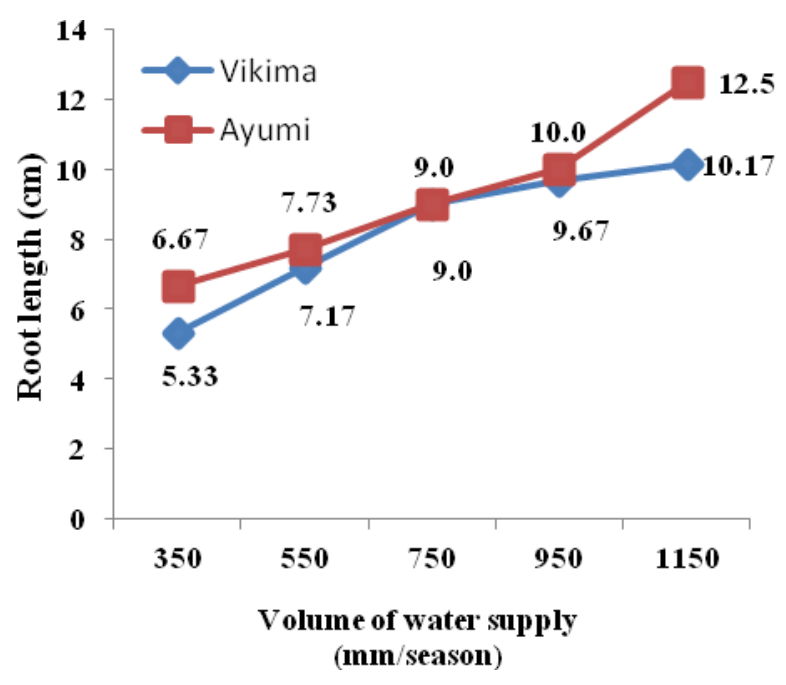

Fig.11: The response of the two red beetroot varieties to the root length at various volumes of water supply

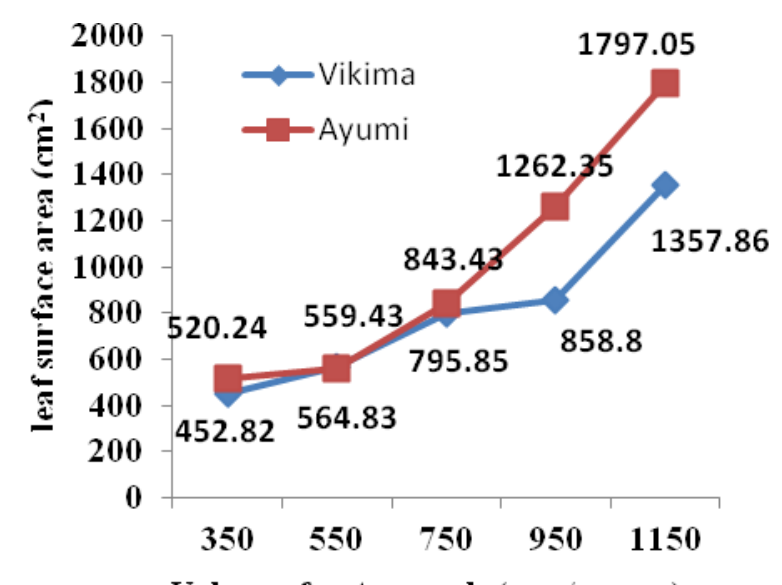

Volume of water supply ( $\mathrm{mm} /$ season)

Fig.12: The response of the two red beetroot varieties to the leaf surface area at various volumes of water supply

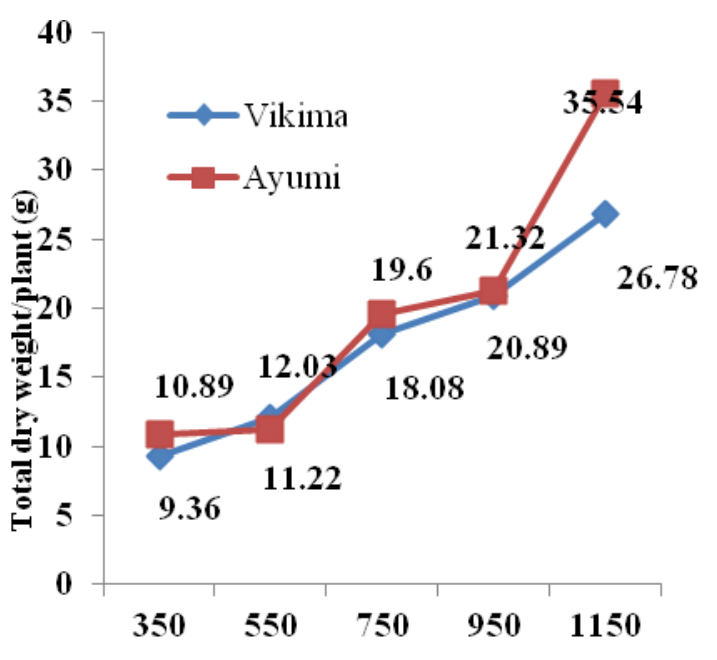

Volume of water supply $(\mathrm{mm} /$ season)

Fig.13: The response of the two red beetroot varieties to the total dry weight of plant at various volumes of water supply

\subsubsection{Tuber fresh weight/plant}

Fresh weight of tubers / plant affected by the treatment of the water supply volume and varieties. Average fresh weight of tuber / plant at different volume of water supply and varieties are presented in Table 6. 
Table 6. Average of tuber fresh weight/ plant in various combination treatment of water supply and varieties at harvest (60 daps)

\begin{tabular}{|c|c|c|c|}
\hline \multirow[b]{2}{*}{ Treatment } & \multirow[b]{2}{*}{ Code } & \multicolumn{2}{|c|}{ Tuber fresh weight/plant } \\
\hline & & & $(\mathrm{g})$ \\
\hline $350 \mathrm{~mm}$ of water/ season + Vikima varieties & $\mathrm{P} 1$ & 29.70 & $\mathrm{a}$ \\
\hline $550 \mathrm{~mm}$ of water/ season + Vikima varieties & $\mathrm{P} 2$ & 61.10 & $\mathrm{c}$ \\
\hline $750 \mathrm{~mm}$ of water/ season + Vikima varieties & P3 & 87.67 & $\mathrm{~d}$ \\
\hline $950 \mathrm{~mm}$ of water/ season + Vikima varieties & $\mathrm{P} 4$ & 104.09 & $\mathrm{~d}$ \\
\hline $1150 \mathrm{~mm}$ of water/ season + Vikima varieties & P5 & 144.76 & $\mathrm{e}$ \\
\hline $350 \mathrm{~mm}$ of water/ season + Ayumi varieties & P6 & 34.31 & $\mathrm{ab}$ \\
\hline $550 \mathrm{~mm}$ of water/ season + Ayumi varieties & P7 & 57.46 & $\mathrm{bc}$ \\
\hline $750 \mathrm{~mm}$ of water/ season + Ayumi varieties & P8 & 98.31 & $\mathrm{~d}$ \\
\hline $950 \mathrm{~mm}$ of water/ season + Ayumi varieties & P9 & 111.47 & $\mathrm{~d}$ \\
\hline $1150 \mathrm{~mm}$ of water/ season + Ayumi varieties & $\mathrm{P} 10$ & 193.78 & $\mathrm{f}$ \\
\hline
\end{tabular}

HSD 5\% 25.20

Note: Numbers are accompanied by the same letters in the same column are not significantly different by HSD 5\%. dap: days after planting.

Table 6 shows that the highest fresh weight of tubers / plants was obtained at treatment P10, which was $193.78 \mathrm{~g} /$ plant, compared to other treatments. While the lower one was obtained at treatments P1 and P6, respectively 29.70 and $34.31 \mathrm{~g} /$ plant. Although for the P6 treatment, the fresh weight of the tubers produced did not differ significantly at $\mathrm{p}=0.05$ with the P7 treatment (ie $57.46 \mathrm{~g} /$ plant), and the treatment was also not significantly different from the P2 treatment, which was $61.10 \mathrm{~g} /$ plant. fresh weight of tuber/plant showed no significantly different at $\mathrm{p}=0.05$ for the treatment P3, P4, P8, and P9, respectively by $87.67,104.09,98.31$ and $111.47 \mathrm{~g} /$ plant. However, the four results are still higher than the treatments P1, P6, P2, and P7, although lower than the P5 and P10 treatments which have reached values of 144.76 and $193.78 \mathrm{~g} /$ plant. On the other hand to evaluate the response of each variety to the fresh weight of tubers/plants in various water distributions is presented in Fig. 14.

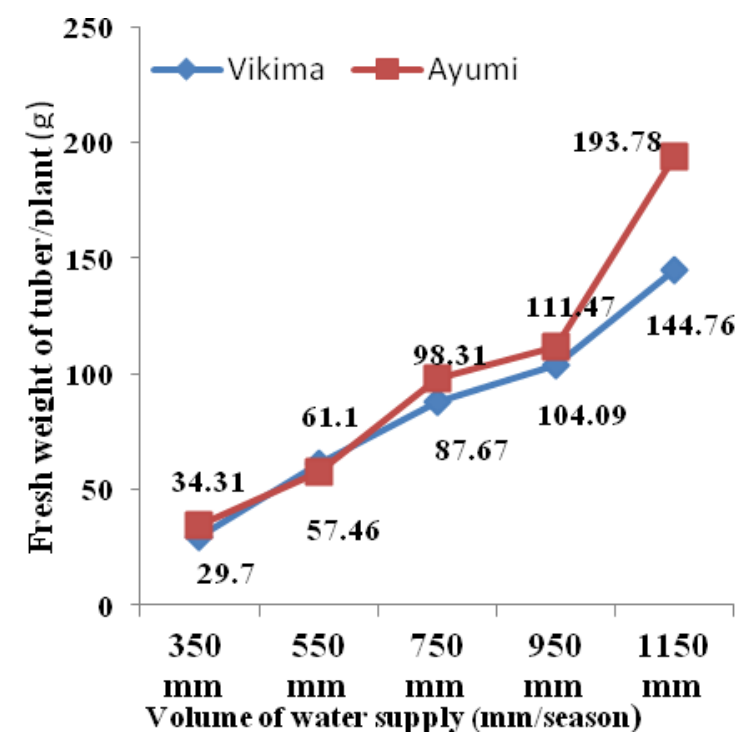

Fig 14: The response of the two red beetroot varieties to the fresh weight of the tuber/plant at various volumes of water supply

\subsection{DISCUSSION}

\subsubsection{Chlorophyll content}

Measurement of chlorophyll content can be used as an indicator to determine crop water shortages. The results showed that the higher content of chlorophyll-a $\left(\mathrm{C}_{55} \mathrm{H}_{72} \mathrm{O} 5 \mathrm{~N}_{4} \mathrm{Mg}\right)$ and chlorophyll-b $\left(\mathrm{C}_{55} \mathrm{H}_{70} \mathrm{O}_{6} \mathrm{~N}_{4} \mathrm{Mg}\right)$ was 
obtained in treatments P5 and P10. While the lower one was obtained in treatments P1 and P6 (Table 3). The lower chlorophyll content produced by treatments P1 and P6 as a result of the low level of water availability for plants due to the low volume of water supplied. In limited water conditions, there is an inhibition in the process of nitrification. As a result, the process of conversion of nitrite $\left(\mathrm{NO}_{2}{ }^{-}\right)$to nitrate $\left(\mathrm{NO}_{3}{ }^{-}\right)$is disturbed that causes $\mathrm{N}$ to be less available for plants. On the other hand with low levels of water availability also causes low levels of nutrient solubility (especially elements $\mathrm{N}$, and $\mathrm{Mg}$ ). This has led to low uptake of these elements when the two elements are very important in relation to the preparation of chlorophyll [ 1 ]. Thus it can be said that for plants that are in limited water conditions, chlorophyll biosynthesis is inhibited. Chlorophyll biosynthesis inhibition was also fueled by the low availability of carbohydrates, conditions of temperature and light absorption [8]. At hightemperature conditions such as in the study site, it will spur an increase in the rate of evapotranspiration which causes plants to experience a water deficit, especially for plants that are only watered as much as $350-550 \mathrm{~mm} /$ season. The incidence of wilting is unavoidable, and this is one of the physiological responses of plants that lack water. As a result, the rate of photosynthesis decreases, and this decrease has an impact on the low assimilate produced. Though this assimilate is needed in chlorophyll biosynthesis. Hence, when crops suffer from lack of water, chlorophyll biosynthesis and carbohydrate disturbed. As a result, the amount of chlorophyll formed is also low, as presented in Table 3. These results are in line with [13] who found that the ratio of chlorophyll $\mathrm{a}, \mathrm{b}$ in plants that lack water is lower (ie, 2.16), compared to the control treatment, which reached 3.29 These results are also supported by the high value of $\mathrm{R}^{2}$ generated from both the regression equation (Fig 15). The resulting linear form of the equations illustrates that the level of chlorophyll content that forms is determined by the extent of the water available for plants.

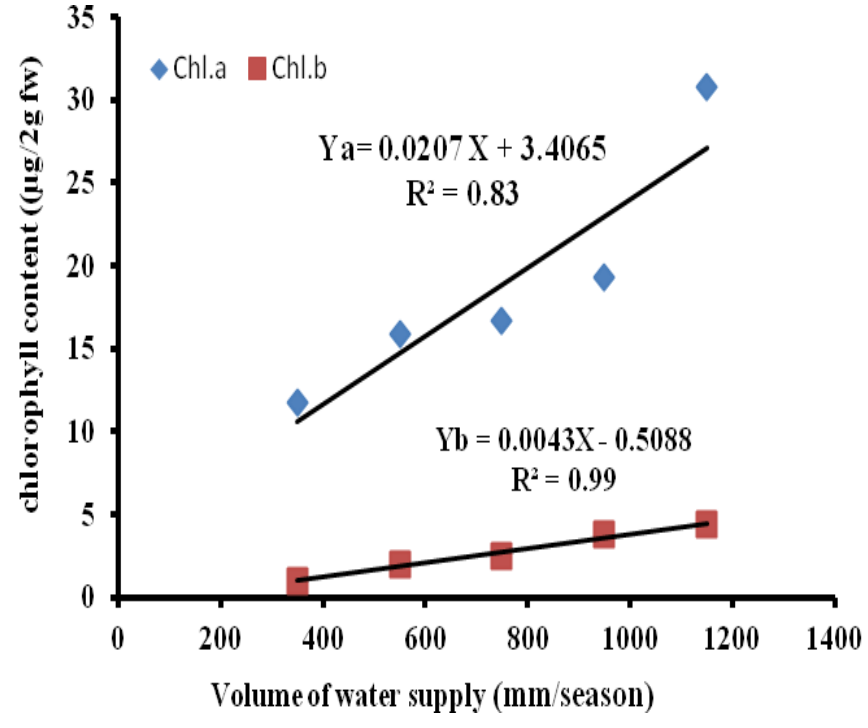

Fig. 15. The relationship between the volume of water supply and the chlorophyll content

\subsubsection{Stomata density}

Table 4 shows that a higher density of stomata were obtained in the treatment of P5, P9 and P10. While the lower was obtained in treatment P1, P2, P6, and P7 (Table 4). The lower density of the stomata is closely related to the efforts of plants to reduce more water loss, especially through the process of transpiration when water is limited [14 ] stated that some important strategies developed by plants when subjected to drought are to reduce the number and density of stomata, and stomatal closing quickly. This aims to reduce the amount of water loss from the body of the plant through the process of transpiration. This is in line with the results of research by [4] who informed that the transpiration rate in maize decreased by around $54.21 \%$ when it was only watered by $30-40 \%$ of field capacity. However, it then showed an increase of $30.24 \%$ (from 30 $40 \%$ of field capacity) when it was irrigated as much as $70-$ $80 \%$ of field capacity. This means that the decline in the rate of transpiration is closely linked to the low density of stomata that are generated, and the high number of stomata that experience closure. On the other hand, the closing of stomata is also caused by increased synthesis and release of abscisic acid (ABA). The presence of ABA in the root is caused by an increase in $\mathrm{pH}$ in the root xylem vessels. As a result, there is an $\mathrm{ABA}$ flow from the roots to the shoots (leaves), and ABA accumulation in the leaves causes stomata to close [ 26]. This statement is reinforced by the results of stomata density measurements as presented in Figures 1 to 10 . The figure shows the difference in stomata density between treatments. In the provision of high water, ranging from 750 to $1150 \mathrm{~mm} / \mathrm{season}$, both in the Vikima and Ayumi varieties (P3-P5 and P8-P10), the level of 
stomata density produced is higher than $\mathrm{P} 1, \mathrm{P} 2, \mathrm{P} 5$, and $\mathrm{P} 6$. However, there is a tendency that the level of stomata density in the Ayumi variety is higher than that of the Vikima variety in various volumes of water supply. This indicates that the Ayumi variety is more adapted than the Vikima variety.

\subsubsection{Root length}

Drought stress is a term used to state that plants suffer from lack of water due to the limited water from their environment, especially in their growing media. The results showed that the longest root was obtained in the P10 treatment. Whereas the shorter one was found in the treatments P1, P2, P6, and P7 (Table 5). The shorter roots produced by the four treatments are as a result of (1) the low content of chlorophyll a and chlorophyll b, (2) the low level of stomata density, all of which are caused by low levels of water availability for plants. Water for plants not only serve as a solvent, but also plays a role in regulating the opening and closing of stomata. Stomata will open when turgor pressure from both guard cells increases. While increasing the turgor pressure of the guard cells is determined by the entry of water into the guard cells. When guard cells take water through osmosis, guard cells will swell causing stomata to open. The stomatal opening will soon spur the photosynthetic activity when other factors are also met. Therefore, plants that suffer a lack of water will have an impact on the low assimilate due to closed stomata. As a result, the rate of plant growth decreases, including the process of root development [26]. The shorter roots are also caused by the high obstacles that must be passed by the roots due to quite dense and hard growing media used, so it takes a lot of energy. Meanwhile, assimilate available low. As a result, the roots are not able to develop normally. [5] also found that black potato plants were irrigated as much as $300 \mathrm{~mm} / \mathrm{season}$, root length produced shorter, that is $42.40 \mathrm{~cm}$, while for crops to be irrigated as much as $1200 \mathrm{~mm} / \mathrm{season}$, root length output reached $52.54 \mathrm{~cm}$. Fig. 11 shows that the Ayumi variety has a better level of adaptability than the Vikima variety at various volumes of water supply. Thus, the length of the root produced is generally longer than the Vikima variety

\subsubsection{Leaf surface area}

Leaves are photosynthetic organs for plants. Therefore, leaf surface area needs to be observed in this study. The results showed that the widest leaf surface was found in P10 treatment, which was $1,797.05 \mathrm{~cm}^{2}$ (Table 5). This is due to the higher chlorophyll content and the longer root formed (Table 3.5). The high chlorophyll content will spur the rate of photosynthesis due to more light that can be captured by the leaf chlorophyll. In addition, the absorption of nutrients by the roots runs normally because the roots are able to develop normally. Considering the growth and development of plants requires a certain amount of energy, the energy that formed in the form of assimilates will be used for this process, including the expansion of leaves. However, the increase in the leaf area is not always followed by the increase in the total dry weight of the plant. The regression analysis proved the quadratic relationship between leaf area $(\mathrm{X})$ with a total dry weight of plants (Y) given by an equation: $\mathrm{Y}=-0015 \mathrm{X}^{2}+47.38$ $X-9347.9 ; R^{2}=0.99$. This equation shows that with increasing leaf area to its optimum limit, it is still followed by an increase in the total dry weight of plants. However, an increase in leaf area above the optimum causes a reduction in the total dry weight of the plants produced. Based on these equations, it can be determined the optimum leaf area for beet plants planted in dryland is $1,579.33 \mathrm{~cm}^{2}$ with a maximum total dry weight of $28.07 \mathrm{~g} /$ plant. Conversely, if crops suffer from lack of water, whether caused by the low volume of water provided and because of the dry conditions of the atmosphere, causing a lack of imbalance between the rate of evapotranspiration and water availability levels. As a result, crops suffer from water stress and result in physiological and morphological changes that may occur at the molecular and cellular levels [16]. Physiological and morphological changes are shown as a result of water stress is (1) a decrease in the rate of growth of plants due to the low assimilate produced, (2) impaired and chlorophyll biosynthesis inhibition due to lower $\mathrm{N}$ and $\mathrm{Mg}$ uptake by plants is a constituent element klorofil [ 1 ]. (3) The reduction of leaf surface area serves to keep the cell potential remains high. In this condition, cell turgidity remains high, so the rate of water loss can be minimized. This was also proven in this study which found that the narrowest leaf surface area was produced by treatments $\mathrm{P} 1$ and $\mathrm{P} 6$, where the water provided was the lowest, ie $350 \mathrm{~mm} / \mathrm{season}$ (Table 5). Reduction in leaf surface size is actually a response of plants when experiencing water shortages, namely by changing the new assimilate distribution, from leaves to roots. Besides aiming to control the high rate of transpiration. The purpose of the change is to support root growth in an effort to increase the capacity of water absorption by plant roots [22]. Fig. 12 shows that the Ayumi variety showed better growth than the Vikima variety in various water supplies. This indicates that the Ayumi variety is more tolerant than the Vikima variety.

\subsubsection{Total dry weight of plants}

In this study, the highest total dry weight of plants was obtained in the P10 treatment, amounting to $35.54 \mathrm{~g} /$ plant. While the lower is obtained in the treatment of P1, P2, P6, 
and P7 (Table 5). The lower total dry weight of the plants produced is related to (1) lower chlorophyll a-b formation (Table 3), (2) narrower surface area of the leaves produced (Table 5), (3) shorter roots ( Table 5), and (4) lower levels of stomata density produced (Table 4). When the four factors necessary to the plant is limited, then the limitations that will restrict the growth and development of plants [15, 1]. While the total dry weight of plants is a function of growth, and when the plant growth process is disrupted, the total dry weight of the plants produced is also low due to the non-maximum function of each plant organ [23]. These results concur with those of [20] were informed that the taro plants watered as much as $500 \mathrm{~mm}$ of water/season, total dry weight of plants produced amounted to $9.53 \mathrm{~g} /$ plant, and this value is $73.95 \%$ lower than the with irrigated as much as $1000 \mathrm{~mm} / \mathrm{season}$ reached $36,59 \mathrm{~g} /$ plant. Regression analysis also proved the existence of a linear relationship between water requirements $(\mathrm{X})$ and total plant dry weight $(\mathrm{Y})$ through the following equation: $\mathrm{Y}=0.014 \mathrm{X}+0.08, \mathrm{R}^{2}=0.94$. The high coefficient of determination which reached 94 indicates that the total dry weight of plants, $94 \%$ is determined by wate Fig. 13 shows that in general, the total dry weight of plants produced by the Ayumi variety is higher at various volumes of water supply than the Vikima variety. This indicates that the Ayumi variety is more adaptive than the Vikima variety.

\subsubsection{Tuber fresh weight / plant}

The economic yield of red beet plants in the form of tubers, and based on this study it was found that the highest fresh weight of tubers/plants was obtained at P10 treatment, which was $193.78 \mathrm{~g} /$ plant. While the lower was found in treatment P1 and P6 (Table 6). The lower tuber weight is due to the lower content of chlorophyll $a-b$ produced (Table 3 ), the lower density of stomata formed (Table 4), the shorter root produced (Table 5), the narrower surface area of leaves (Table 5) ), all of which are important factors and determine the development of a plant. As a result, the physiological processes of plants are disturbed, especially photosynthesis. Obstructed and disruption of this process will result in a low assimilate formed. Whereas assimilate is the main energy source for the plant. [14 ] states that the energy that is formed will be used for energy growth, as energy reserves, and partly to be stored in the sink which is an economic yield of plants (tubers). Given the importance of the assimilate function, it causes the plants to have limitations as mentioned above, resulting in disruption of plant physiological processes, especially photosynthesis which finally has disrupted the process of forming and filling the bulbs [2]. It becomes reasonable when treatment $\mathrm{P} 1$ and $\mathrm{P} 6$, the fresh weight of tuber/plant produced low. In addition, the tuber weight is also determined by the level distribution of assimilates from the source to the sink (bulb) can be measured through a formula EY/TDW [ 21]. EY is tuber dry weight, while TDW is total plant dry weight, and based on this study it was found that higher EY / TDW was obtained in treatments P5 and P10, respectively $64.04 \%$ and $65.31 \%$. This indicates that approximately $64-65 \%$ of the total assimilated generated has been allocated to the tuber. As for the P1 treatment only reaches $43.06 \%$ and amounted to $50.81 \%$ for the treatment of P6. This has led to a lower fresh weight of tubers/plant on care $\mathrm{P} 1$ and $\mathrm{P} 6$ respectively reaching only 29.70 and $34.31 \mathrm{~g} /$ plant. These results concur with those of [20] on taro plants which showed that the irrigation of $500 \mathrm{~mm} / \mathrm{season}$, the EY/TDW only reach of $0.12 \%$, while the irrigation of $1,500 \mathrm{~mm} / \mathrm{season}$, the EY/TDW irrigation reaches approximately $0.19 \%$. Fig.14 shows that the Ayumi variety has a better response to various water supply volumes to the fresh weight of tubers/plants than the Vikima variety. Although statistically, not all treatments are able to produce significant differences. However, the fresh weight of tuber/plant produced by Ayumi varieties has a higher tendency than Vikima varieties.

\section{CONCLUSION}

Based on these results, it can be concluded that in order to get the best plant growth, the highest yield, as well as the best physiological aspects of red beet plants planted in the dry land, it needs irrigation as much as $1150 \mathrm{~mm}$ of water/season by using the Ayumi variety (P10).

\section{ACKNOWLEDGEMENT}

The author would like to thank the Dean of the Faculty of Agriculture, Brawijaya University for providing Plant Breeding Laboratory, Plant Physiology Laboratory, Environmental Resource Laboratory, and Climatology Laboratory, where the authors conduct analysis, measurement, and borrowing equipment to support research activities. The author is also grateful to laboratory assistants, as well as field officers who have assisted in conducting this research activity.

\section{AUTHORS CONTRIBUTION}

Nur Edy Suminarti as the main researcher, contributed to the design of this study, starting from the determination of 
treatment, experimental design, stages of observation, and writing of this manuscript.

Tika Noviana Dewi as a research assistant, contribute in determining the location of research, implementing the research in the field and help the observations in the field

Aninda Nur Fajrin as a research assistant, contributed to data analysis and data collection on observations

\section{REFERENCES}

[1] Ai, N.S., and Y.Banyo, Concentration of leaf chlorophylles as a water lack indicator. Jurnal Ilmiah Sains, 2011. 11(2) : 1-8.

Available from:

https://www.researchgate.net/publication/334230139_KONS ENTRASI_KLOROFIL_DAUN_SEBAGAIINDIKATOR KEKURANGAN_AIR_PADA_TANAMAN.

[Accessed January 19, 2020]

[2] Akram, H.M., A.Ali, A.Sattar, H.S.U.Rehmanand, A.Bibi, Impact of water deficit stress on various physiological and agronomic trait of three basmati rice (Oryza sativa L.) cultivars. J.of Animal \& Plant Sci., 2013. 23 (5):1415-1423.

Available from: http://www.thejaps.org.pk/docs/v-23$\underline{5 / 30 . p d f}$

[Accessed December 13, 2019]

[3] Anasyuraiddah, Measurement of chlorophyll content in leaves with Spectrophotometry. 2009

Available from: http://Spektrofotometer.com.

[Accessed September 15, 2019]

[4] Anggraeni, N., E. Faridah, S.Indrioko, Effect of drought stress on physiological behavior and growth of black locust seedlings (Robinia pseudoacacia). Jurnal Ilmu Kehutanan, 2015.9 (1) : 40-56

Available from:

https://jurnal.ugm.ac.id/jikfkt/article/view/10183

[Accessed January 1, 2020]

[5] Ardani, P.D., N.E. Suminarti, A.Nugroho, Response of black potatoes (Solenostemon rotundifolius) to various amounts and frequencies of water supply. J. Biotropika, 2017. 5 (3): $119-132$.

Available from:

https://lavasoft.gosearchresults.com/?sbtn=\&q=Respon+Tan aman+Kentang+Hitam+\%28Solenostemon+Rotundifolius\%

29+pada+Berbagai+Jumlah+dan+Frekuensi+Pemberian+Air $\& \mathrm{tt}=\mathrm{VM} \quad$ GS S4LAVA $\mathrm{vmn}$ webcompa 100 go 1 vs_webcompa 1 1_0 go_ch_WCYID10457_181219_yr ff $\quad$ rff\&pid=5ac784309091147a162b4431\&sr $=0$

[Accessed October 29, 2019]

[6] Asyari, F., Measurement of stomata density in various types of plants, 2014.

Available

from: https://www.academia.edu/9938196/Pengukuran_Kerapatan Stomata Pada Berbagai Jenis Tanaman

[7] Cheginia, M.A., B. Rezaei-radb, S. Ghalebic, Determination of crop transpiration coefficient $(\mathrm{Kc})$ at various growth stages of sugarbeet. Plant Ecophysiology J., 2010. 2 : 31-36
Available from:

file:///E:/SID.ir\%20\%20\%20DETERMINATION\%20OF\%2 0CROP\%20TRANSPIRATION\%20COEFFICIENT\%20(K SUB)C( SUB) $\% 20$ AT\%20VARIOUS\%20GROWTH\%20S TAGES\%20OF\%20SUGARBEET.htm

[Accessed June 3, 2019]

[8] Farooq, M., A. Wahid, N. Kobayashi, D. Fujita, S.M. A. Basra, Plant drought stress: Effects, Mechanisms and Management, 2010.

Available from:

https://link.springer.com/chapter/10.1007\%2F978-90-4812666-8_12

[Accessed January 19, 2020]

[9] Gomez, K.A., \& A.A.Gomez, Statistical Procedures For Agricultural Reseach. ( ${ }^{2}$ Ed.). John Wiley \& Sons, New York, Chichester, Brisbane, Toronto,Singapore, 1984.

[10] Haridjaja, O., D.P.T. Baskoro,M.Setianingsih, Different levels of field capacity by alhricks, free drainage, and pressure plate methods at different soil texture and relation for sunflower growth. J. Tanah Lingkungan, 2013. 15 (2): 52-59 Available

from: https://journal.ipb.ac.id/index.php/jtanah/article/view/11487/ $\underline{8979}$

[Accessed January 19, 2019]

[11]Idjudin, A.A., and S. Marwanto, Reformation of dryland management for supporting food-self sufficiency. J. Sumberdaya Lahan, 2008. 2 (2) : 115-125.

Available from: http://balittanah.litbang.pertanian.go.id/ind/dokumentasi/lain nya/abbas.pdf.

[Accessed November 28, 2019]

[12] Ierna, A., and G. Mauromicale, Physiological and growth response to moderate water deficit of off-season potatoes in a Mediterranean environment. Agric.Water Manag., 2006. 82 (1-2): 193-209.

Available from: https://www.sciencedirect.com/science/article/abs/pii/S0378 377405002672

[Accessed April 3, 2019]

[13]Karki, D., W.Wyant III, , W.A. Berzonsky, K. D. Glover, Investigating physiological and morphological mechanisms of drought tolerance in wheat (Triticum aestivum L.) lines with 1RS translocation. American J.of Plant Sci., 2014. 5 :1936-1944.

Available from: https://file.scirp.org/pdf/AJPS_2014061914590585.pdf [Accessed January 19, 2020]

[14]Lestari, E.G., The relation between stomata index and drought resistant at rice somaclones of Gajahmungkur, Towuti, and IR 64. J. Biodiversitas, 2006. 46 (1) : 44-48.

Available from: https://issuu.com/biodiversitasunsjournals/docs/d070100$\underline{\text { all } / 52}$

[Accessed December 9, 2019]

[15] Liu,F., C.R.Jensen, M.N. Andersen, Drought stress effect on carbohydrate concentration in soybean leaves and pods 
during early reproductive development: its implication in altering pod set. J. Field Crop Res., 2004. 86 (1): 1-13.

Available

from:

https://www.sciencedirect.com/science/article/abs/pii/S0378 429003001655\#!

[Accessed January 10, 2019]

[16] Maisura, M. A.Chozin, I. Lubis, A.Junaedi, H. Ehara, Some physiological character responses of rice under drought conditions in a paddy system. J. of the International Society for Southeast Asian Agricultural Sciences, 2014. 20 (1) :104-114.

Available from:

https://www.researchgate.net/publication/282180298_Some_ physiological_character_responses_of_rice_under_drought_ conditions_in_a_paddy_system

[Accessed October 29, 2019]

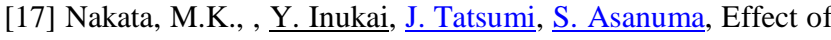
various intensities of drought stress on variation among plant organs in rice: Comparison of two cultivars. American J. of Plant Sci., 2014. 05 (11):1686-1693.

Available from: https://www.researchgate.net/journal/2158$\underline{2742}$

[Accessed December 15, 2019]

[18] Nandadc, The health benefits of fruit, 2014

Available

from:

https://manfaatbuahkesehatan.blogspot.com/p/contact-

us.html.

[Accessed November 28, 2019]

[19] Nanema, R.K.,E.R.Traore,P. Bationo Kando, and J.D.Zongo, Morphoagronomical characterization of Solenostemon rotundifolius (Poir. J.K. Morton) (Lamiaceae) germplasm from Burkina Faso. Int.J.Biol.Chem.Sci., 2009. 3 (5) : 11001113

Available from:

https://lavasoft.gosearchresults.com/?sbtn=\&q=morphologic al+characterization+of+solenostemon+rotundifoliu\%28Poir + J.K.Morton\%29\%28lamiaceae\%29+gemplasm+from+Burk ina+faso.\&tt=VM_GS S4LAVA_vmn_webcompa _ 1 0 go lvs _webcompa _1_0_ go _ch_WCYID10457_18 1219 _yrff_yrff\&pid $=5$ ac784309091147a162b4431\&sr $=0$ [Accessed January 3, 2020]

[20] Nurchaliq, A., M. Baskara, N. E. Suminarti, Pengaruh jumlah dan waktu pemberian air pada pertumbuhan dan hasil tanaman talas (Colocasia esculenta (L.) Schott var. Antiquorum). Jurnal Produksi Tanaman, 2014. 2(5) : 355 360.

Available from: http://protan.studentjournal.ub.ac.id/index.php/protan/article/ view/118/114

[Accessed October 13, 2019]

[21]Pahlevi, R.W. and N.E.Suminarti, Effect of combination proportion of nitrogen and potassium fertilization on growth, yield and quality of sweet potato (Ipomea Batatas (L.) Lamb) varieties of cilembu in lowland plains. Jurnal Produksi Tanaman, 2016. 4 (1) : 16 - 22

Available

from

https://lavasoft.gosearchresults.com/?sbtn $=\& q=E f f e c t+o f+C$
ombination+Proportion + of + Nitrogen + and + Potassium + Fert ilization + on + Growth\% $2 C+$ Yield + and + Quality $+o f+$ Sweet + Potato+\%28Ipomea +Batatas+\%28L.\%29+Lamb\%29+Varie ties + of + Cilembu + in + Lowland + Plains. $+\& t t=V M \quad G S \quad S 4 L$ AVA_vmn webcompa 1_O go lvs webcompa 1_0 go ch WCYID10457 181219 yrff yrff\&pid=5ac78430 $9091147 a 162 b 4431 \& s r=0$

[Accessed September 25, 2019]

[22] Sikuku, P. A., G.W. Netondo, J. C. Onyango, and D. M. Musyimi, Effect of water deficit on physiology and morphology of three varieties of nerica rainfed rice (Oryza sativa L.). ARPN J. of Agric. and Biol.Sci., 2010. 5 (1): 2327

Available from: http://arpnjournals.com/jabs/research_papers/rp_2010/jabs_0 110_169.pdf

[Accessed December 30, 2019]

[23] Sujinah dan A.Jamil, Mechanism response of rice under drought stress and tolerant varieties. Iptek Tanaman Pangan, 2016. 11 (1): 1-8. Available from: http://pangan.litbang.pertanian.go.id/files/01iptek11012016Sujinah.pdf

[Accessed December 30, 2019]

[24] Suminarti, N.E., F.Riza, A.N. Fajrin, 2020. Effect of paranet shade on the four green bean in Jatikerto dryland Indonesia. Asian J.Crop.Sci., 2020. 12 (2): 63-71.

Available from:

https://scialert.net/fulltext/?doi=ajcs.2020.63.71

[Accessed February 5, 2020]

[25] USDA, Data Content of Beetroot (Red Beetroot). 2019, Available from: https://ilmupengetahuanumum.com/kandungan-gizi-buahbit-ubi-bit-merah-manfaat-buah-bit-bagi-kesehatan/. [Accessed November 28, 2019]

[26] Xiong, L., R.G. Wang, G. Mao, J.M. Koczan, Identification of drought tolerance determinants by genetic analysis of root response to drought stress and abscisic Acid. Plant Physiol., 2006. 142 : 1065-1074.

Available from:

http://www.plantphysiol.org/content/142/3/1065.

[Accessed January 1, 2020] 